\title{
A Revista Feminina e a moda em tempos de guerra (1914-1918)
}

The Revista Feminina and the fashion in times of war (1914-1918)

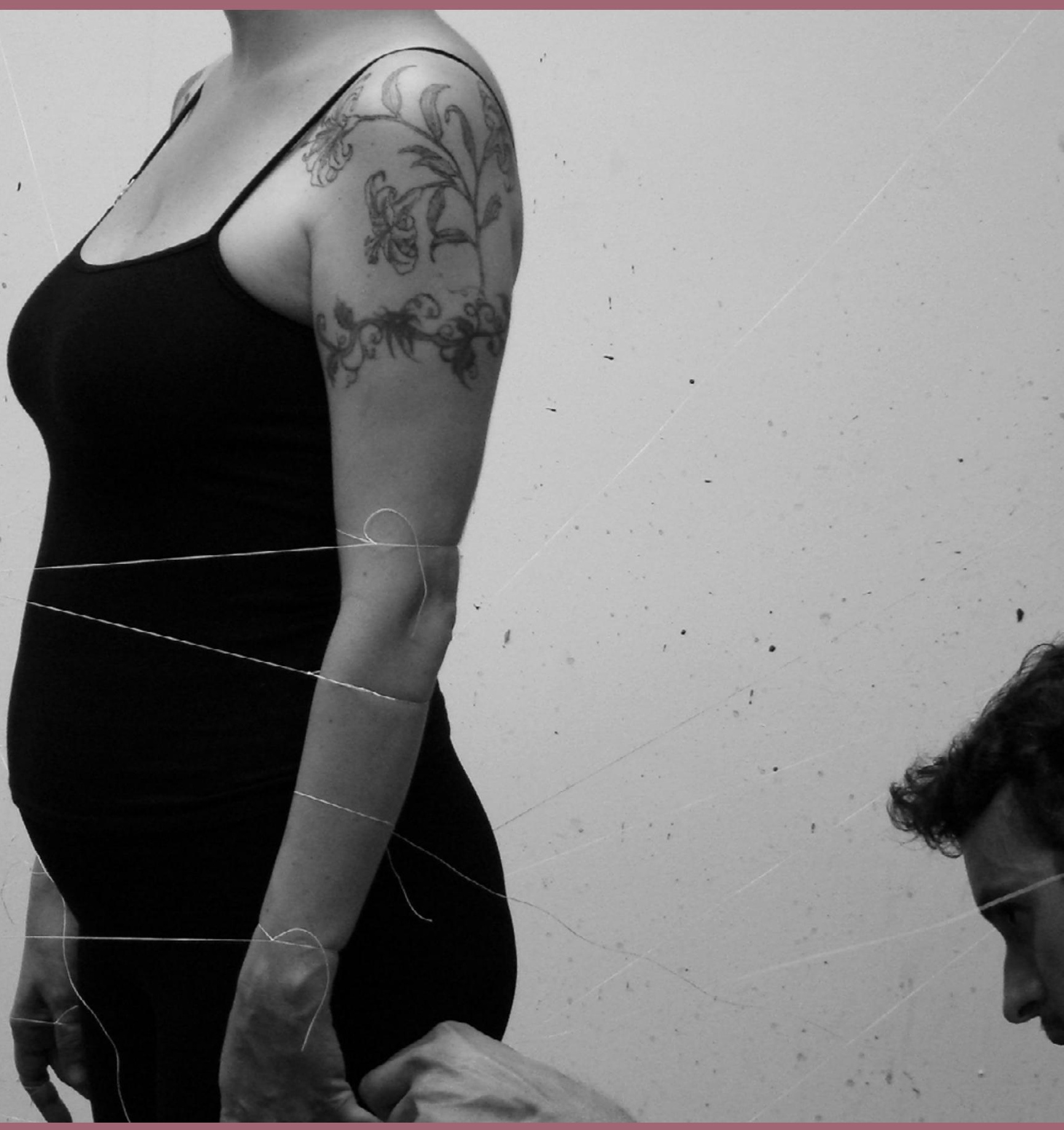




\section{Sílvia Maria Azevedo}

ORCID: https://orcid.org/0000-0001-7679-1919

[resumo] Periódico de grande sucesso de público e vendagem, a Revista Feminina (1915-1936), fundada por Virgilina de Souza Salles, figura proeminente da elite paulistana, tinha por objetivo orientar as leitoras sobre questões domésticas e conscientizá-las em relação às causas femininas (direito ao voto, trabalho fora do lar) em um momento de grande expansão do movimento feminista. Entre as seções de temas variados que caracterizam a Revista Feminina, cabe destacar aquela assinada por Marinette e que atendia pelo título "A Moda", espaço acompanhado de ilustrações (desenhos, fotografias), voltado à informação acerca da moda proveniente de Paris, disponível nas grandes lojas de departamento de São Paulo, como La Saison e Mappin Stores. Deflagrada a Primeira Guerra Mundial, os impactos do conflito repercutiram de maneira significativa no território da moda, quer no desaparecimento das linhas fluidas e das saias justas da época eduardina, quer no papel da mulher na sociedade, que assumia o lugar dos homens em fábricas de munição, escritórios e lojas. Reflexos das mudanças na moda, decorrentes da guerra, se fizeram sentir na seção "A Moda", da Revista Feminina, na qual Marinette, além de comentá-las, informava as leitoras sobre as razões de tais mudanças. 0 objetivo do artigo é analisar a referida seção da Revista Feminina e propor uma reflexão de ordem social e cultural quanto ao posicionamento da revista paulistana, por intermédio da cronista Marinette, a respeito das transformações na indústria da moda durante os anos da Primeira Guerra, e suas ressonâncias no comportamento das mulheres.

\section{[palavras-chave] Revista Feminina. Primeira Guerra Mundial. Moda.}

[abstract] A publication of great success and impressive selling, the magazine Revista Feminina (1915-1936) - founded by Virgilina de Souza Salles, a prominent figure of the São Paulo elite - had the objective of guiding its readers on domestic issues and making them aware of popular causes in a moment of great expansion of the feminist movement (the right to vote and to work). Among the sections in the magazine approaching various topics, it is worth mentioning the one signed by Marinette, which was named Fashion, accompanied by illustrations (such as drawings and photographs) and focused on information about fashion from Paris, available in major department stores in São Paulo, such as La Saison and Mappin. World War I had a significant impact on the field of fashion, not only in the disappearance of fluid lines and fair skirts of the Edwardian era but also in the social role of women, who took the places of men in the ammunition factories, as well as offices and shops. Reflections on the changes in fashion as a result of the war were evident in the Fashion section of the magazine Revista Feminina, where Marinette, in addition to commenting on them, informed the readers about the reasons for such changes. The purpose of this article is to analyze the said section of Revista Feminina and propose a social and cultural reflection on the position of the magazine through the texts written by Marinette about the transformations in the fashion industry during the years of the First War, as well as its resonances in the behavior of women.

[keywords] Revista Feminina. World War I. Fashion.

Recebido em: 19-01-2019

Aprovado em: 06-07-2019

1 Profa. Dra. Livre-Docente de Teoria Literária no departamento de Literatura da Faculdade de Ciências e Letras da Universidade Estadual Paulista Júlio de Mesquita Filho, Assis (SP). E-mail: silrey@uol.com.br. Lattes: http://lattes.cnpq.br/7179920962384971. 
No mesmo ano em que estourou a Primeira Guerra Mundial na Europa, do lado de cá do Atlântico, mais exatamente na capital do Estado de São Paulo, em junho de 1914, era lançada a revista A Luta Moderna, dirigida por Virgilina de Souza Salles, o marido, João Salles, e o escritor e dramaturgo Cláudio de Souza, irmão de Virgilina, figuras de destaque da tradicional elite paulistana. Em janeiro de 1915, a publicação passa a se chamar Revista Feminina ${ }^{2}$, título que irá manter até 1936, quando João Salles “[...] preferiu fechar o periódico a vendê-lo, temeroso de que seus objetivos e os princípios morais que nortearam a linha editorial do periódico fossem deturpados" (MASCARO, 1982, p. 17 citado por BONADIO, 2000, p. 139).

Enquanto circulou sob o título de A Luta Moderna, não passava de um pequeno folheto de conteúdo apolítico, no formato de um jornal quinzenal de quatro páginas e com matérias bastante diversificadas. Ao receber a denominação de Revista Feminina, torna-se empreendimento de distribuição mensal, voltado exclusivamente aos interesses femininos, representados, sobretudo, pelas mulheres das classes média e alta. Porta-voz das causas femininas, ainda que em tom moderado, em um momento em que o movimento feminista já se fazia ouvir em várias partes do mundo, nem por isso a Revista Feminina ficou imune à influência da Igreja, contando com a participação de intelectuais católicos no seu quadro de colaboradores (LOPES, 1991).

Publicado pela Empresa Feminina Brasileira, órgão de desenvolvimento, promoção, redação e divulgação da Revista Feminina, o periódico da família Salles destacava-se pela sua concepção editorial e empresarial, antecipando uma tendência que seria prevalecente na imprensa feminina, ao abarcar grande variedade de temas (embora com predominância de assuntos domésticos), abordados em uma perspectiva voltada para o lado comercial, e ao contribuir para a integração da mulher em uma sociedade cada vez mais urbanizada (BUITONI, 1981).

Empreendimento de vulto, já em 1916, a Revista Feminina contava com quase cem páginas de texto, cerca de duzentas ilustrações e uma tiragem de 15 mil a 20 mil exemplares. As sucursais e agências filiadas à revista mantinham extensa rede de distribuidores por vários estados (Pernambuco, Alagoas, Paraíba, Rio Grande do Norte), além de pequenas agências que atuavam a fim de angariar assinaturas e atrair colaboração feminina, com sedes em Manaus, Belém, Salvador, Fortaleza, Corumbá, Belo Horizonte, Niterói, Campinas, Curitiba e Florianópolis. A ajuda e a influência de Cláudio de Souza foram decisivas no sentido de promover a circulação da Revista Feminina ao reunir mais de 60 mil endereços por todo o território brasileiro e enviar, gratuitamente, 30 mil exemplares com o objetivo de angariar assinaturas.

Como iniciativa comercial, cujo intuito era vender produtos voltados ao público feminino e à esfera doméstica, a Revista Feminina passou a inserir, desde os primeiro números, anúncios de magazines, com destaque para as lojas de vestuário feminino, como La Saison, Mappin Stores e Casa Allemã, entre outras que expunham suas roupas, comentadas depois por Marinette na seção sob sua responsabilidade. Espaço fixo da revista destinado a divulgar novidades no tocante a roupas, acessórios e penteados, a seção, que se inicia com o título

2 Abaixo era mantido, entre parênteses, A Luta Moderna, jan./abr. 1915. 
"Notas sobre a Moda” e, em 1915, passa a se chamar "A Moda”, cresce rapidamente, chegando a contar com cerca de três páginas por edição, o que aponta para o seu sucesso.

A grande receptividade da seção "A Moda" pelo público feminino está associada a um momento em que, na cidade de São Paulo, "[...] o desenvolvimento comercial e a expansão da moda acontecem em conjunto com as transformações que a cidade sofre em virtude da transferência da elite cafeeira da área rural para a capital do Estado a partir de 1890" (BONADIO, 2000, p. 45-46). Com isso, "[...] São Paulo passa a ser um bom local para investimentos nacionais e estrangeiros nas mais diversas áreas, dentre as quais se destacam as indústrias, o comércio e os serviços" (BONADIO, 2000, p. 46).

A Exposição Industrial de 1917, realizada no Palácio das Indústrias em São Paulo, por iniciativa do prefeito Washington Luís, pode ser tomada como expressão do pensamento industrial paulista, assim também do processo modernizador da cidade. A ideia de que a exposição representaria um grande benefício para a região e para a indústria, divulgada pelos principais jornais da capital paulista, como $O$ Estado de S.Paulo, Correio Paulistano, Jornal do Commercio e A Platea (LIMA, 2012), era compartilhada pela Revista Feminina que, em matéria publicada em novembro de $1917^{3}$, engrossava o coro dos órgãos da imprensa que, em coalizão com o poder público, ajudavam “[...] a forjar a imagem de São Paulo como uma das grandes metrópoles modernas, com incalculáveis potencialidades de progresso" (LIMA, 2012, p. 21).

Muito embora a eclosão da Primeira Grande Guerra possa ter destruído “[...] o sonho do progresso ilimitado e escancarado as falhas daquele sistema capitalista e industrial [...]" (LIMA, 2012, p. 12), os organizadores da Exposição Industrial de 1917 em São Paulo veem aquele como um momento privilegiado para indústria nacional que, finalmente, encontrava “[...] espaço para se desenvolver à medida que a concorrência externa diminuía” (LIMA, 2012, p. 12).

O fato de o Brasil permanecer desde 4 de agosto de 1914 oficialmente neutro em relação à declaração de guerra do Império Austro-Húngaro à Sérvia pode também ter contribuído para que o país, mantendo-se à margem do conflito europeu ${ }^{4}$, vivesse durante certo tempo relativo clima de paz e prosperidade, muito embora a economia brasileira, na época extremamente dependente da exportação do café, logo seria afetada pelo bloqueio naval estabelecido pela Grã-Bretanha aos produtos dos países neutros (VINHOSA, 1990).

Do outro lado do Atlântico, a França, que havia declarado guerra a Alemanha, em 3 de agosto de 1914, era palco de lutas sangrentas, responsáveis por tirar a vida de milhares de pessoas e a sinalizar que aqueles não eram tempos para se falar sobre moda, conforme relata Marinette, na crônica de junho de 1915:

\footnotetext{
3 Exposição Industrial na cidade de São Paulo, Revista Feminina, ano 4, n. 42, novembro de 1917 , s.p.

${ }^{4} \mathrm{Na}$ imprensa brasileira, vários políticos, escritores e jornalistas defendiam a entrada do Brasil na guerra. Ver: REGO, Ana Regina; LEAL, Ranielle. Imprensa brasileira na Primeira Grande Guerra: intelectuais em ação. ALCAR 2015. 10 o Encontro Nacional de História da Mídia, UFRGS/Porto Alegre/ Rio Grande do Sul, 3 a 5 de junho de 2015.
} 


\begin{abstract}
Nos primeiros meses da guerra, em um autobus, em Paris, duas senhoras francesas conversavam sobre moda. Um oficial que em frente a elas se achava, parecia com o seu olhar censurá-las por aquelas frases que elas trocavam quase automáticas, pelo hábito de todo o dia.

Como pensar em modas, como pensar nas futilidades deliciosas que ocupam a alma feminina nos dias de paz, quando o País inteiro se batia?

Numa das paradas do autobus o oficial levantou-se para sair. Uma das senhoras pergunta à outra:

- Qual será a cor em voga na próxima estação?

- Será com certeza o preto - disse o oficial enervado - que é a cor do luto... (MARINETTE, Revista Feminina, n. 13, 1915, p. 7) ${ }^{5}$
\end{abstract}

Ainda assim, a cronista da Revista Feminina consegue vislumbrar os "efeitos benévolos" (MARINETTE, n. 14, 1915, p. 18) da guerra sobre o vestuário feminino, as roupas extravagantes e suntuosas, usadas antes da conflagração, dando lugar à simplicidade e à praticidade no trajar, as saias justas cedendo espaço a saias curtas e amplas que, entre outras comodidades, facilitavam os movimentos. Nem sempre, porém, comodidade e praticidade, em termos de acessórios femininos, foram bem recebidas por Marinette, sobretudo quando as mulheres substituíram os chapéus pelo "[...] famoso e horrível gorrinho em todas as cores, uns em guirlanda de margaridas, outros mais ricos, com um paradis" (MARINETTE, $n$. 14, 1915, p. 19), em relação ao qual a autora não esconde sua aversão:

Eu o abomino - e muitos homens me têm confessado que sentem pelo tal gorrinho a mesma abominação. A mulher que mete aquilo na cabeça não quer tirar mais. É cômodo e é barato. Com um pedaço de papelão e um pedaço de seda por cima - aí estamos nós armadas de um gorrinho para o que der e vier! (MARINETTE, n. 15, 1915, p. 18)

A desaprovação da cronista estende-se também aos novos modelos que, provenientes de Paris, não deixam dúvida de que a inspiração da moda vem do front da batalha:

Que há a dizer sobre a moda? Quase nada. Entraram no Rio, mais que em São Paulo, os costumes-uniforme - só agora! - as rabonas a Jofre, os costumes a Kaiser... É tudo quanto há de mais deselegante, de mais absurdo e antiestético. As mulheres dentro de tais uniformes dão ideia dos manequins articulados de porta de casa de seringueiro. (MARINETTE, n. 15, 1915, p. 18)

Em sintonia com a crítica de Marinette aos "costumes-uniforme”, as ilustrações que acompanham a crônica de 15 de agosto de 1915 não se referem a tais modelos, mas a um

\footnotetext{
${ }^{5}$ A partir daqui, nas demais citações de Marinette não será feita referência à Revista Feminina, visto que todas são extraídas desse periódico.
} 
vestido de tule preto bordado de vidrilho, para baile ou teatro, confeccionado pela casa La Saison. Apenas quando a sugestão militar na moda tornar-se mais palatável para a cronista, como no caso de um conjunto de saia e blusa para ser usado nas práticas esportivas ou a passeio, em que a blusa apresentava "ligeira sugestão militar" (MARINETTE, n. 16, 1915, p. 17), a descrição da roupa é compatível com a imagem (figura 1).

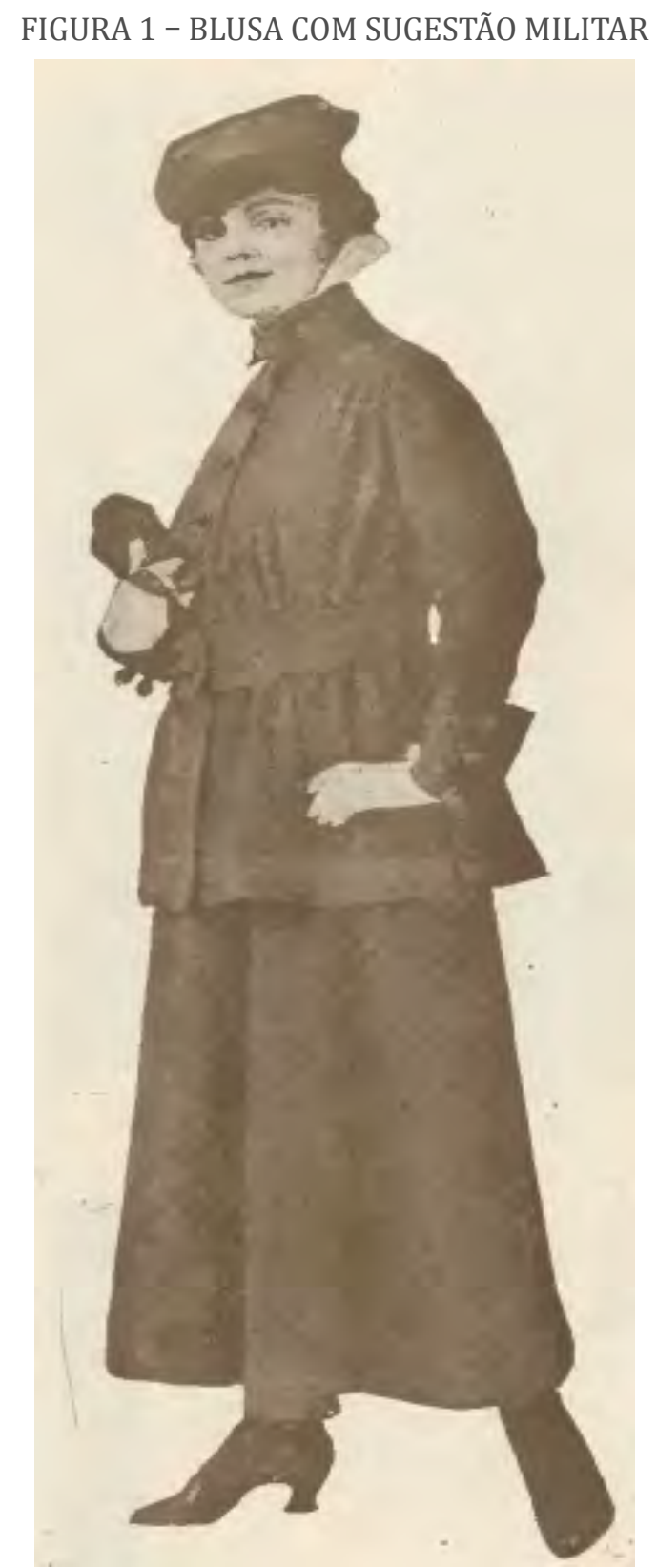

FONTE: Revista Feminina, ano 2, n. 16, setembro de 1915.

Apesar dos embargos da Inglaterra à circulação de navios brasileiros com carregamento de café para a Europa, com repercussões na vida econômica nacional, as propagandas 
de lojas de vestuário, como Mappin Stores, inseridas na Revista Feminina, fazem supor que o mundo da moda, em São Paulo, não havia sido afetado pela guerra. Os transatlânticos Liger e Garrona, da França, e Darro e Amazon, de Londres, continuavam a importar as últimas novidades europeias para o verão de $1917^{7}$, a serem consumidas pelas mulheres da elite paulistana, clientes preferenciais do Mappin Stores. Essa clientela exclusiva era também incentivada, a partir da propaganda, a incorporar certos hábitos ingleses, como o de sair de casa para tomar chá às cinco da tarde, o tradicional five o'clock tea, em um salão especialmente reservado da loja, o tea room, "[...] um aprazível lugar para descanso, onde se pode gozar de agradável palestra, e desfrutar um encantador panorama de São Paulo e arrabaldes”8 (figura 2).

\section{FIGURA 2 - PROPAGANDA DO MAPPIN STORES}

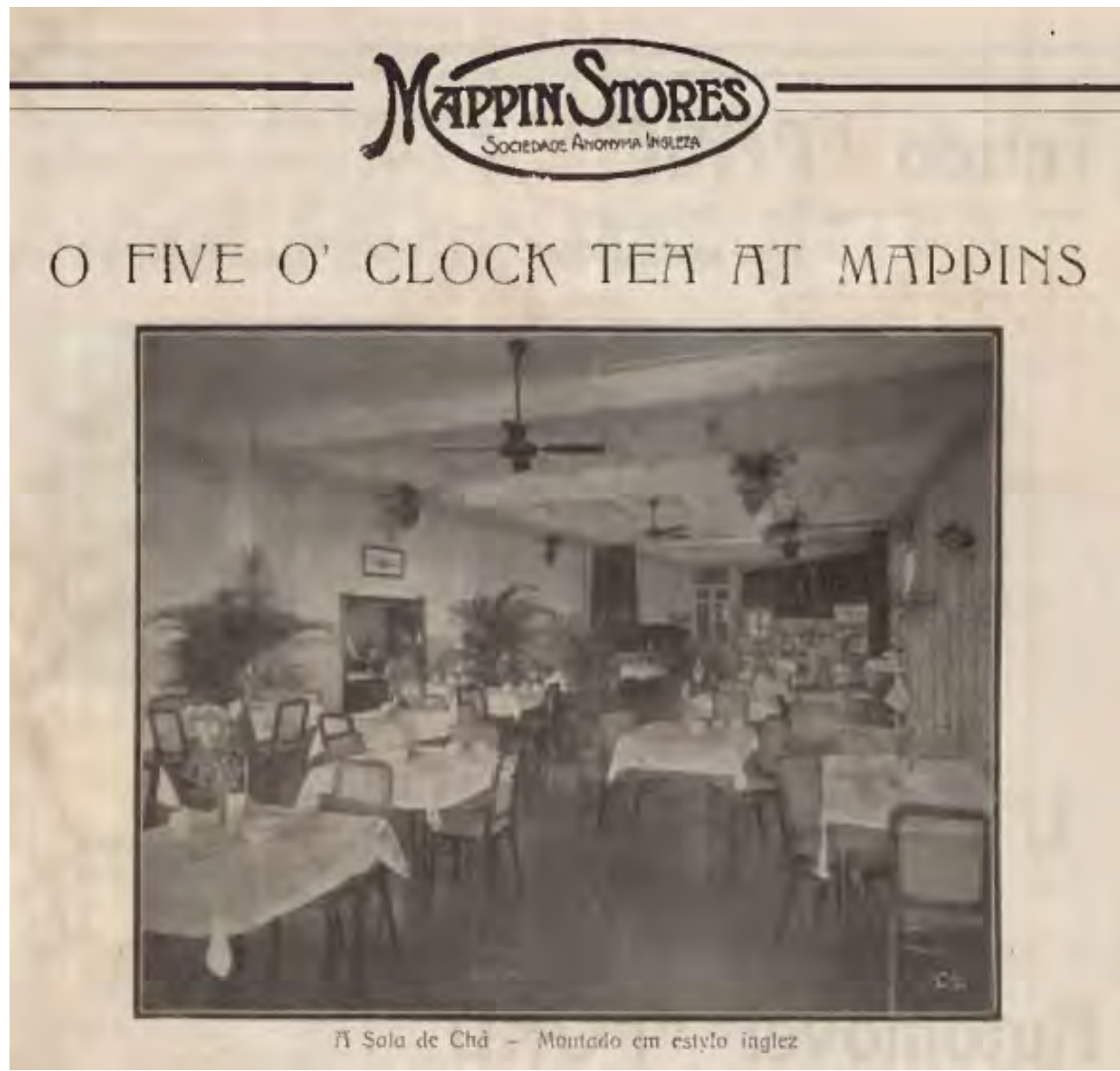

FONTE: Revista Feminina, ano 2, n. 22, março de 1916.

\footnotetext{
${ }^{6}$ Ver: ALVIM, Zuleika; PEIRÃo, Solange. Mappin: 70 anos. São Paulo: ExLibris, 1985. CAVALCANTI, Pedro; DELION, Luciano. São Paulo, a juventude do centro. São Paulo: Grifo, 2004.

Propaganda da Mappin Stores, Últimas importações de Paris e Londres, Revista Feminina, ano 3 , n. 42, novembro de 1917.

${ }^{8}$ Propaganda Mappin Stores, 0 five o’clock tea at Mappins, Revista Feminina, ano 3, n. 22, março de 1916.
} 
A volta do véu, no entanto, que as mulheres tinham posto de lado quando, a partir de 1910, passaram a exibir os rostos maquiados, com o emprego de cosméticos caseiros ou industriais, é um dos sintomas da influência da guerra no mundo feminino. A carestia dos produtos e a falta de matéria-prima são as principais causas de as francesas passarem a usar o véu para não exibirem as faces pálidas e ressequidas, conforme noticia Marinette na crônica de março de 1916:

\footnotetext{
O véu voltou? pergunta-me por carta, uma das leitoras desta seção. "Voltou, sim, senhora!" [...].

Voltou e está fazendo furor em Paris. Aliás era coisa de esperar. Com a guerra a francesa deixou de pintar-se; o maquillage de que tanto se abusava [...] foi aos poucos perdendo a voga. Umas não se pintavam porque a morte de um ente querido, em campanha, lhe roubara da alma a alegria; outras, porque com a conflagração as tintas subiram de preço e a glicerina deixou de fazer parte da beleza feminina, para se ocupar exclusivamente com o fabrico de explosivos.

[...]

Desaparecida a pintura - a maquillage dos nossos franceses - as faces mostraram-se um tanto ressequidas e desmerecidas. [...]

E foi assim que voltou o véu, que já ia caindo em abandono. (MARINETTE, n. 22, 1916, p. 25)
}

Em que pese o papel fundamental da autora no sentido de atualizar as leitoras quanto às últimas tendências da moda em Paris, é provável que a direção da Revista Feminina estivesse torcendo para que o véu não fosse adotado pelas brasileiras, para não comprometer as propagandas de produtos de beleza veiculadas na revista, como as tinturas de cabelo Petalina e o creme facial Dermina, de propriedade de Cláudio de Souza.

Além de responder às cartas das leitoras, a cronista da seção "A Moda" da Revista Feminina não se furtava, a partir do próprio exemplo, a incentivá-las a cometer pequenos delitos em nome da redução dos gastos com a moda. Como foi o caso da descoberta de uma humilde modista, moradora de um dos arrabaldes de São Paulo, que confeccionava belíssimos chapéus pelos quais cobrava muito barato:

As minhas leitoras sabem que uma descoberta de tal ordem, vale muito mais do que a descoberta da América, para uma elegante de poucos haveres, que pode obter por meio dela dois chapéus, em vez de um, com o mesmo dinheiro! (MARINETTE, n. 24, 1916, p. 22)

De volta para casa, depois de comprar um belo chapéu “[...] por um preço ridículo, que ainda consegui com abatimento [...]" e de prometer à modista que lhe mandaria algumas freguesas, embora sem nenhuma intenção de fazê-lo, conforme ela mesma confessa, 
Marinette não hesitou em trocar a etiqueta original por outra da Rue de la Paix ${ }^{9}$, arrancada de um chapéu velho:

A etiqueta de uma modista desconhecida de arrabalde não podia recomendar o lindo chapéu ao meu círculo, ainda que ele fosse um encanto. As minhas amigas faziam vir de Paris e mesmo de Paris, só adotavam a rua de la Paix. (MARINETTE, n. 24,1916, p. 22)

A voga do tailleur de seda, acompanhado de colete, que as mulheres passaram a usar como traje de noite, se, por um lado, atendia à necessidade de ordem econômica de simplificar a toilette feminina, por outro, evoluía para que, muito em breve, nos jantares e nas soirées de gala, se observasse, na previsão pessimista de Marinette, "[...] a monotonia de dois uniformes, um masculino, o smocking e outro feminino, o tailleur habillé [...]" (MARINETTE, n. 26, 1916, p. 22).

Daí a cronista acolher com entusiasmo a vitória da França sobre a Alemanha, na batalha de Verdun em $1916^{10}$, ao prenunciar o fim da Primeira Grande Guerra e o consequente desafogo para o mundo da moda:

No começo da guerra, efetivamente, as preocupações e as incertezas que marcam os primeiros dias de qualquer terremoto, fizeram com que toda a gente se retraísse, diminuísse as despesas e tomasse precauções explicáveis, para um período de sofrimento, cuja extensão ninguém podia prever. Veio depois o luto, a toilette severa. Agora, com a nova feição que a guerra tomou começaram já a aparecer cores mais claras e certas superfluidades que se explicam pela confiança que a todos os espíritos ganha, do próximo fim da guerra. (MARINETTE, n. 29, 1916, p. 20)

Apesar das expectativas sobre Verdun, a guerra não acabou. Ao contrário, ela tornou-se ainda mais encarniçada, a artilharia e a infantaria passaram a contar com o reforço de uma nova modalidade de aviões na guerra aérea - os zepelins, “[...] dirigíveis gigantes em formato de charuto, inventados pelos alemães, e que levavam pavor às maiores cidades inglesas, especialmente Londres" (MONTEIRO, 2014, p. 26).

A Revista Feminina não deixará de registrar a ameaça dos zepelins para as populações de Londres e Paris ao reproduzir um quadro que “[...] traduziu bem a angústia de uma pobre moça, que passa toda a noite ao relento, olhando o céu, no horror de ver despenharem-se das nuvens as bombas incendiárias" (REVISTA FEMININA, n. 44, 1918, s.p.). É de se

\footnotetext{
${ }^{9}$ Rue de la Paix, rua do comércio elegante no centro de Paris, famosa pelas casas de moda, como a do costureiro inglês Charles Frederick Worth (1825-1895), pioneiro no desfile de coleções prontas e no surgimento da roupa assinada.

${ }^{10}$ A Batalha de Verdun foi um combate entre a França e a Alemanha, entre 21 de janeiro e 19 de dezembro de 1916, nos arredores de Verdun, nordeste da França.
} 
notar, na imagem, a elegância da mocinha, a roupa impecável, os cabelos bem penteados, as pernas à mostra, deixando ver o par de sapatos de salto alto, imagem incompatível com o momento de dor e medo que a ameaça dos zepelins quer sugerir (figura 3).

FIGURA 3 - ZEPELINS CAEM SOBRE LONDRES

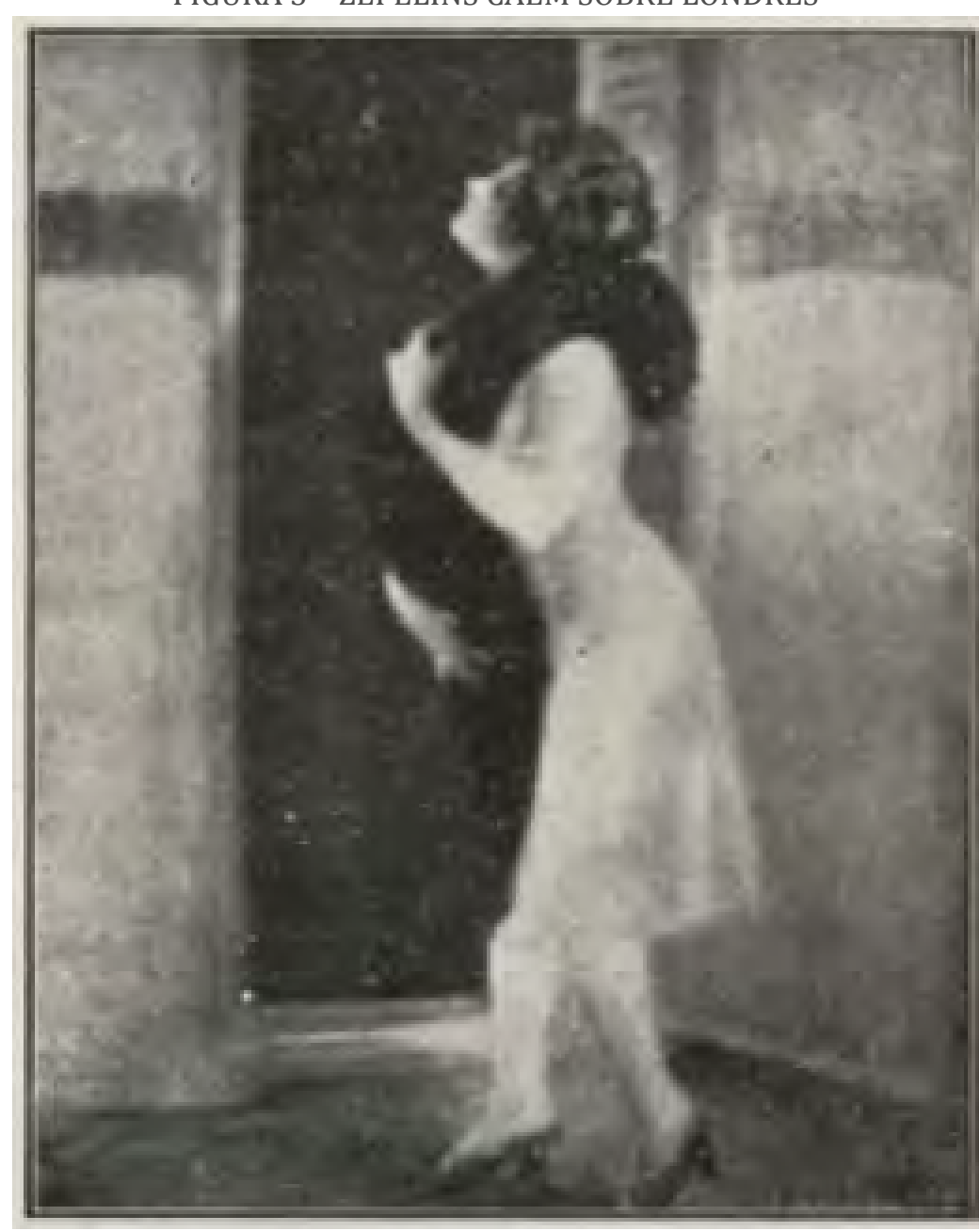

FONTE: Revista Feminina, ano 5, n. 44, janeiro de 1918.

Não apenas a guerra europeia dificultava a atuação de Marinette, que em várias crônicas lamenta "[...] o estado estacionário da moda [...]" (MARINETTE, n. 40, 1917, s.p.), mas também a greve geral dos operários em 1917, que paralisou os setores da indústria, do comércio e de transportes em vários estados do Brasil, sobretudo São Paulo, Rio de Janeiro, Rio Grande do Sul e Paraná, ocasionada pelos baixos salários, o alto custo de vida e as péssimas condições de trabalho (MONTEIRO, 2014, p. 51). Por não ser área de sua competência, a cronista da Revista Feminina tem a desculpa para não comentar o principal motivo da revolta, a carestia dos alimentos, e sim observar que, com o uso da saia curta, as mulheres terão que se esmerar na escolha do calçado (MARINETTE, n. 39, 1917, s.p.) (figura 4). 


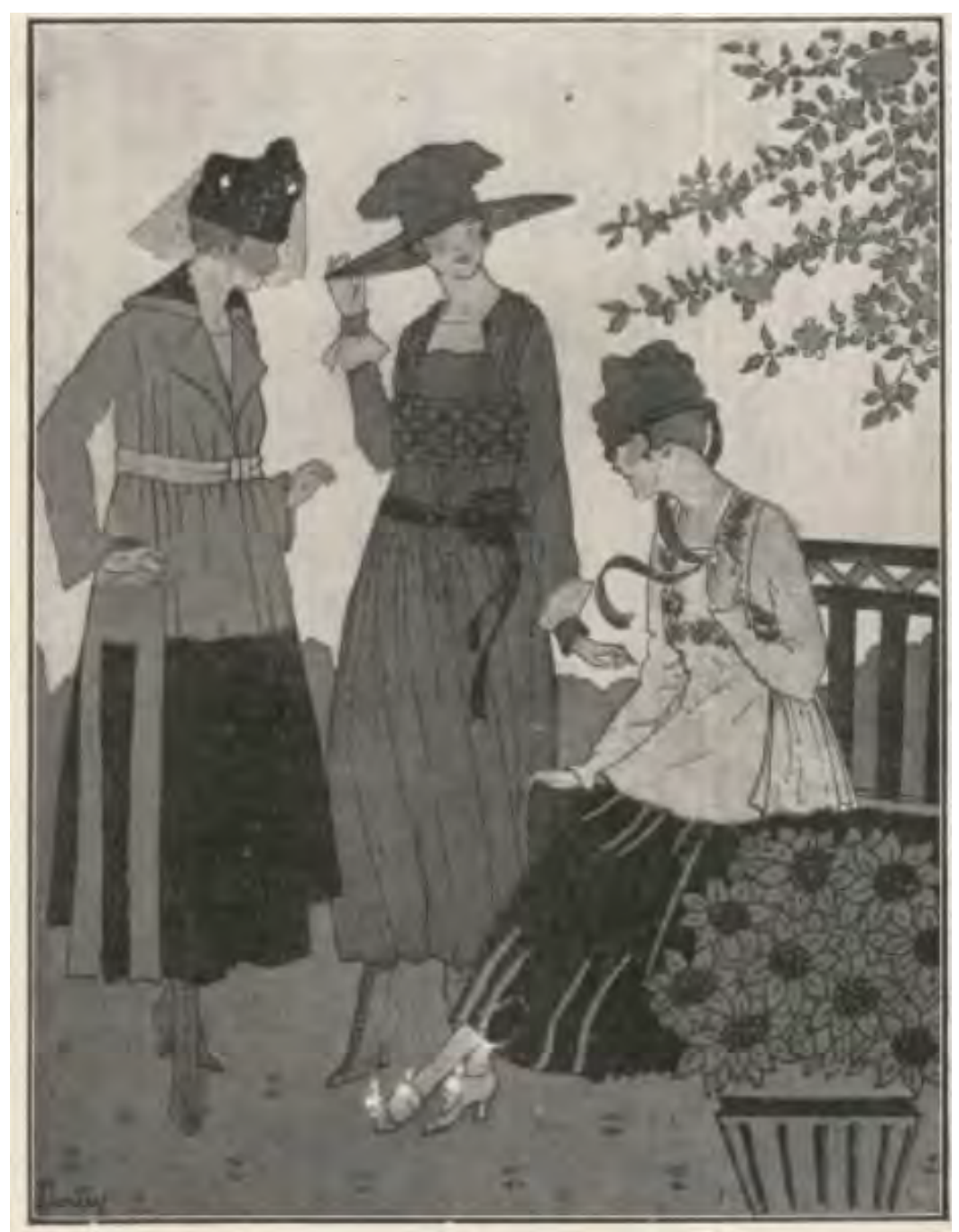

FONTE: Revista Feminina, ano 4, n. 39, agosto de 1917.

Em tempos de conflitos internos e externos, a única novidade que os figurinistas europeus inventaram e procuravam impingir às "[...] amantes do modernismo [...]" (MARINETTE, n. 40, 1917, s.p.), a saia tonel, Marinette não somente desaprova - "Já viram coisa bastante esquisita a gente metida em um tonel?" (MARINETTE, n. 34, 1917, s.p.) -, como espera que as elegantes brasileiras, seguindo o seu exemplo, também o façam:

Eu não creio absolutamente no sucesso da linha barril: é uma moda nova e usada prematuramente. Felizmente já lá vão 3 longos meses que os figurinos estão querendo nos impingir essa nova silhueta - (três meses para a moda é um século)! E não estou vendo aceitação por parte de nossas elegantes. Quero crer que esta moda das saias tonneaux terá a mesma sorte das jupe-culotte. As senhoras elegantes não a usarão. (MARINETTE, n. 34, 1917, s.p.) (figura 5) 


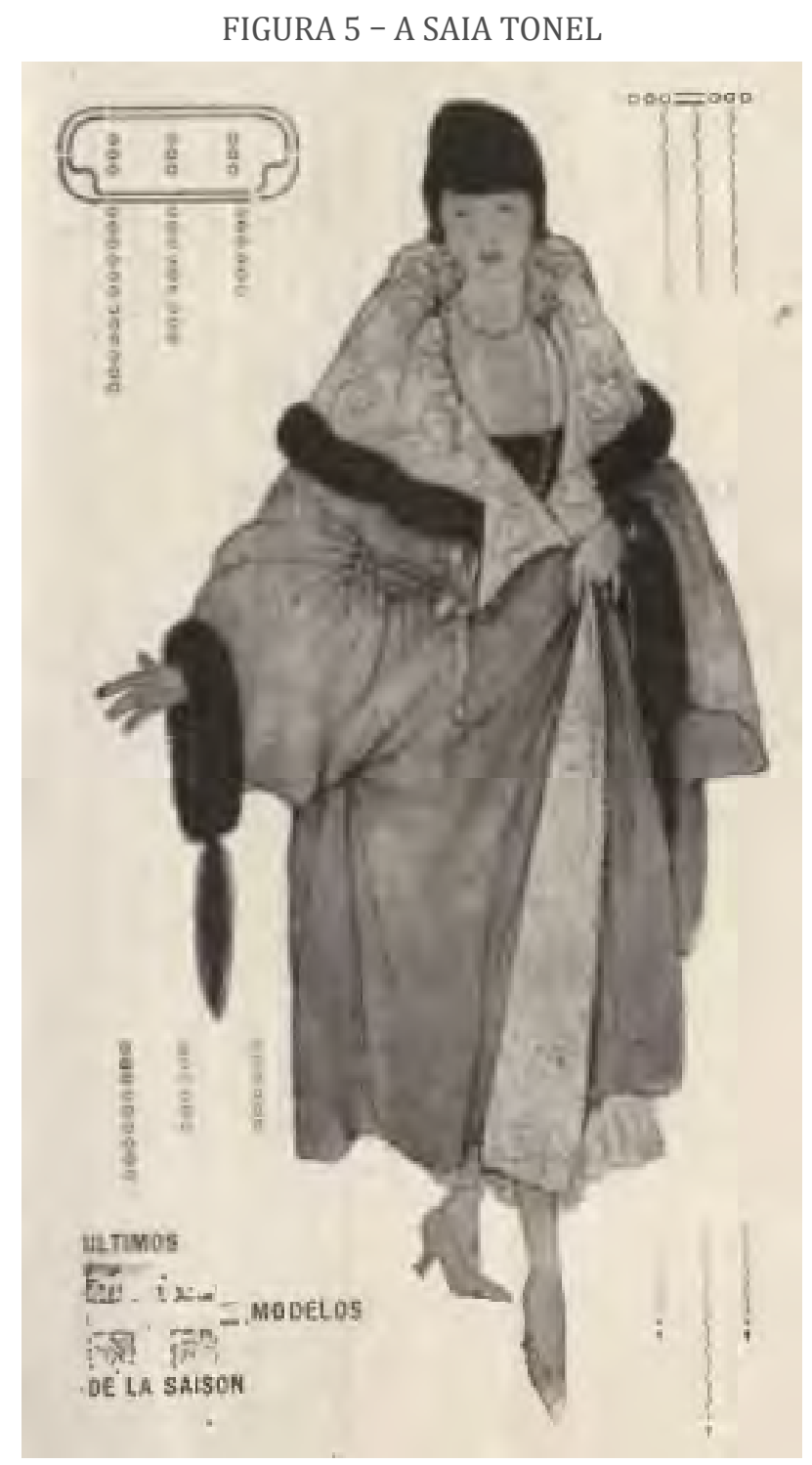

FONTE: Revista Feminina, ano 4, n. 34, março de 1917.

Na falta de novidades, a cronista de moda vai tratar das cores das roupas femininas, sob o argumento de que "[...] a sorte de um vestido não depende tão somente da fazenda, dos enfeites, do modelo, do talhe, da forma, depende extraordinariamente da cor, o efeito do conjunto" (MARINETTE, n. 40, 1917, s.p.). As cores em moda, em 1917, eram o verde, que "[...] não condiz bem com todas as fisionomias, muito embora seja a nossa predileta como nacionalistas [...]" (MARINETTE, n. 40, 1917, s.p.), e o vermelho, em alusão ao militarismo que despertou "[...] um grande entusiasmo na classe feminina" (MARINETTE, n. 40, 1917, s.p.), decorrente da declaração de guerra do Brasil à Alemanha, em abril daquele ano. Nem por isso a cronista acreditava que "[...] um sentimento belicoso se esteja alastrando entre nós a ponto de as senhoras nossas patrícias invejarem o procedimento das senhoras russas" (MARINETTE, n. 40, 1917, s.p.). 
Embora o alistamento obrigatório recebesse a aprovação de Ana Rita Malheiros, pseudônimo de Cláudio de Souza, responsável pelos editoriais da Revista Feminina, que, em texto publicado em novembro de 1917 - "A mulher brasileira na guerra" -, conclamava as brasileiras a apoiá-la, em vista dos benefícios que representava - “[...] um fator de educação física, de melhoramento da raça, de descaída da sedentariedade; e, também, de aperfeiçoamento moral, pela domesticação de nossa rebeldia [...]" (MALHEIROS, n. 42, 1917, s.p.) -, a efetiva participação da mulher na guerra, como no caso do "[...] batalhão de mulheres russas que marcharam para a frente da batalha [...]" (MALHEIROS, n. 45, s.p.), era vista com desaprovação pela revista, posto que associada a "[...] manifestações mais ou menos ridículas de despropositado feminismo [...]" (MALHEIROS, n. 45, 1918, s.p.).

Para além das cores da moda, 1917 marca também o fim da neutralidade do Brasil na Primeira Guerra Mundial, quando, em abril, o navio brasileiro Paraná, que rumava com destino à França, levando 93 mil sacas de café, foi torpedeado por um submarino alemão (MONTEIRO, 2014, p. 70). 0 anúncio do rompimento das relações com a Alemanha ecoou pelo país na forma de manifestações de apoio ao governo e de revolta contra os tedescos. Em São Paulo, a mensagem do presidente Wenceslau Brás enviada ao Congresso Nacional, no sentido de pôr em prática uma série de medidas de exceção em relação aos cidadãos e às empresas alemãs (MONTEIRO, 2014, p. 265), ocasionou o fechamento, entre outros estabelecimentos comerciais, da Casa Allemã, cujas propagandas de moda na Revista Feminina deixarão de circular em agosto de 1917. Em consonância com a onda de notícias e artigos de caráter antigermânico publicados na imprensa brasileira, Ana Rita Malheiros vai alertar que a colônia alemã, estabelecida no sul do país, poderia se tornar, de um momento para outro, "[...] em grave perigo nacional, mais grave ainda do que a guerra externa” (MALHEIROS, n. 43, 1917, s.p.).

Após a declaração de guerra com a Alemanha, o Brasil aproximou-se dos Estados Unidos ao revogar o estado de neutralidade, "[...] o que comprometia o país com a causa americana e, por consequência, aliada [...]" (MONTEIRO, 2014, p. 120). As repercussões da influência dos Estados Unidos logo se farão sentir no território da moda, como registra Marinette, ao noticiar o uso do pijama de dormir entre as norte-americanas, novidade que surgiu em Paris em 1914, mas que a cronista desaconselha, sobretudo para as mulheres gordas, a partir do exemplo de uma parenta que ao adotá-lo ficou parecendo um elefante (MARINETTE, 1917).

Outras comodidades do vestuário feminino, no entanto, como a abolição dos desconfortáveis espartilhos pelas primeiras versões do sutiã, recebiam larga acolhida pela direção da Revista Feminina, a exemplo das inúmeras propagandas publicadas no periódico. 0 que as publicidades não destacavam era que transformações como essas, de peças íntimas do vestuário feminino, eram decorrência da Primeira Grande Guerra, quando muitas mulheres passaram a trabalhar em fábricas e precisavam usar roupas de baixo que não atrapalhassem os seus movimentos.

Ao lado da comodidade no trajar, a masculinização da mulher, quando passa a usar calça comprida, é também decorrência do conflito europeu, na opinião do autor anônimo que assina o texto "O traje masculino e as mulheres", publicado na Revista Feminina, em outubro de 1918. Para tanto, é invocada a opinião de Max Nordau'11 que havia abordado o assunto em artigo publicado no jornal La Nación, de Buenos Aires, parcialmente transcrito na revista:

${ }^{11}$ Max Nordau (1849-1923), médico, ativista sionista e cofundador da Organização Sionista Mundial. 
Dizem-nos que nos Estados Unidos isto é coisa decidida: que as operárias, que os milhões de mulheres que a guerra tem lançado nas fábricas e que participam valentemente da defesa nacional, deram já o primeiro passo e usam calças. As outras, as que ajudam as suas irmãs e a seus irmãos no esforço comum, fazendo-se úteis nos escritórios e oficinas, seguem o seu exemplo; e até as damas da boa sociedade, as elegantes e requintadas, começam a imitá-las porque o espírito público estabelece uma relação entre o novo traje e a guerra. As damas, ao vestir valorosamente calças, querem demonstrar que elas também reclamam o seu posto no movimento patriótico que arrasta a nação inteira. A Grã-Bretanha marcha ao seu lado; e em França também, cuja adesão é indispensável se a inovação quer conquistar o mundo inteiro, observam-se, ao que parece, algumas veleidades, primeiras tentativas ainda tímidas para unir-se às avançadas americanas e inglesas. (NORDAU, Revista Feminina, n. 53, 1918, s.p.)

De fato, desde que os Estados Unidos entraram na Primeira Guerra Mundial, em abril de 1917, e os homens foram convocados a lutar nos campos da batalha, as mulheres, e não apenas as norte-americanas, viram-se obrigadas a desempenhar funções como a de trabalhar na lavoura, em fábricas de munição ou mesmo a pegar em armas, atividades responsáveis por mudanças no comportamento e no vestuário femininos.

No entanto, a "revolução" simbolizada pelo uso da calça comprida pela mulher, que, segundo Nordau, representa "[...] a materialização da igualdade civil e jurídica da mulher e do homem, quer dizer, do feminismo [...]" (NORDAU, n. 53, 1918, s.p.), é posicionamento que Marinette acolhe com reservas, conforme se lê na crônica "Feminismo e guerra", publicado na Revista Feminina, em novembro de 1918. A mulher só entrou a trabalhar e a produzir "[...] quando essa perspectiva de miséria lhe ensombrou o lar, ao ver o desalento do 'sem trabalho' e do 'esgotado', e ao ouvir as lamentações de fome e de vexame dos seus" (MARINETTE, n. 54, 1918, s.p.). Por isso, para a cronista,

[...] o feminismo enquadra-se [...] nos movimentos de providência, ou de compaixão, ou de solidariedade [...]; mas é, principalmente, um gesto de imolação, de sacrifício de fraquezas que crescem para alentar a força; e nunca, um movimento de revolta, de reação que deva trazer a mulher a engrifar-se com o homem, numa luta estéril e antinatural. (MARINETTE, n. 54, 1918, s.p.)

O fato de a cronista de moda da Revista Feminina ter extrapolado o seu campo de atuação para se manifestar a respeito do movimento feminista, liderado pelas sufragistas inglesas e norte-americanas, vitoriosas na conquista do direito ao voto, em $1918^{12}$, é expressão desse importante triunfo das mulheres, com repercussão nos artigos publicados nas páginas da revista da família Salles, que reiteram o posicionamento conservador da publicação paulistana em relação ao feminismo:

\footnotetext{
12 Em 6 de janeiro de 1918, o parlamento britânico adotou a "Lei de 1918 sobre a representação popular", permitindo que 8 milhões de mulheres, com mais de 30 anos, se inscrevessem nos registros eleitorais.
} 
O movimento feminista iniciado na Inglaterra e nos E. Unidos e intensificado pelas sufragettes, nas vésperas da guerra, acaba de ser coroado pela mais brilhante vitória, o que vem mais uma vez provar que a influência feminina é real e decisiva, quando segue uma orientação firme e sem desfalecimentos. Já mais de uma vez temos afirmado que a nossa Revista não é animada por um programa ultrafeminista, nem veio a campo para reivindicações. Anima-nos, ao contrário, um sentimento conservador e religioso, que é a feição geral da mulher brasileira, sem, no entanto, deixarmos de acompanhar com interesse e entusiasmo as conquistas pacíficas que o nosso sexo vai adquirindo de par com a evolução natural da espécie. (VENCEM AS..., n. 45, 1918, s.p.)

Passado o impacto da vitória do movimento sufragista, Marinette volta à atuação de cronista de moda, sem perder a oportunidade de bater na tecla da influência da guerra no vestuário feminino: as saias curtas e cada vez menos rodadas, em vista do alto preço dos tecidos, as botinas de cano alto, os chapéus a imitar bonés e casquetes militares (MARINETTE, 1918). Nem mesmo o vestuário infantil ficou à margem das repercussões do conflito europeu, tendo em vista a voga das roupas em estilo marinheiro (figura 6), "[...] que os filhos das mais nobres famílias do mundo inteiro [...]" passaram a usar, em vista das "[...] vantagens múltiplas de comodidade e elegância" (MARINETTE, n. 51, 1918, s.p.). A cronista informa ainda que os bonés próprios para serem usados com essas roupas são bordados com os nomes de famosos navios de guerra encouraçados, como Rio de Janeiro, São Paulo, Minas Gerias, Lion, Queen Mary, “[...] nomes que unem a história nossa e a de uma gloriosa nação nossa aliada [a Inglaterra] ao mesmo tempo que se convertem em motivo de orgulho para a criança" (MARINETTE, n. 51, 1918, s.p.).

\section{FIGURA 6 - CRIANÇAS COM ROUPA ESTILO MARINHEIRO}
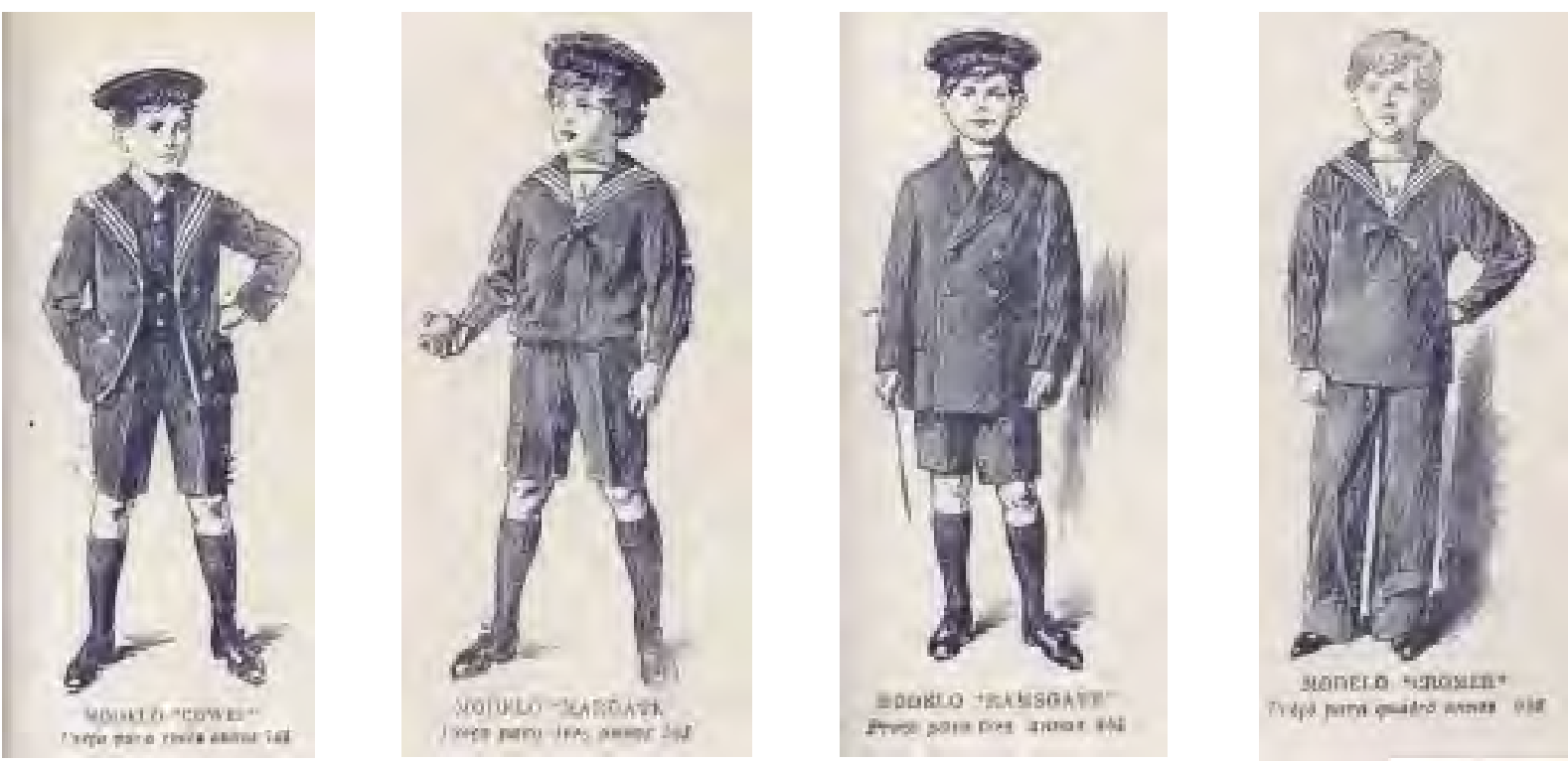

FONTE: Revista Feminina, ano 5, n. 51, agosto de 1918. 
No caso das crianças brasileiras, esse estilo de roupa era ainda mais indicado como preito ao heroísmo dos marinheiros que "[...] a bordo de navios brasileiros defendem no mar as cores da nossa bandeira contra a pirataria germânica [...]" (MARINETTE, n. 51, 1918, s.p.), alusão ao torpedeamento de navios brasileiros pelos alemães, prática constante uma semana depois de o Brasil ter declarado guerra à Alemanha, em 26 de outubro de 1917 (MONTEIRO, 2014). Por sua vez, a menção aos nomes de famosos dreadnoughts, na crônica de Marinette, remete à união entre o Brasil e a Inglaterra, em razão do envio de pilotos brasileiros para serem treinados a fim de combater ao lado dos ingleses (MONTEIRO, 2014).

Quanto mais se prolongava a guerra, mais Marinette se via na obrigação de aconselhar as leitoras da seção de modas da Revista Feminina na contenção de gastos com o vestuário. 0 luxo, a suntuosidade, os tecidos excessivamente ricos eram tidos, naquele momento, como "[...] uma afronta à angustiosa situação do mundo" (MARINETTE, n. 54, 1918, s.p.). Daí o título da crônica de novembro de 1918 - "Elegâncias com roupas usadas" - na qual Marinette precisou usar de muito tato no sentido de não ferir as suscetibilidades de suas seguidoras, começando por desarmá-las quanto a possíveis prevenções contra o título-conselho:

A epígrafe desta notícia poderá, talvez, ferir o escrúpulo de muitas senhoras que são excessivamente cuidadosas e zelosas da sua elegância. Mas não há razão para isso. Atentem elas nos nossos conceitos, e verão que eles são aproveitáveis e francamente adotáveis. (MARINETTE, n. 54, 1918, s.p.)

A argumentação da cronista se centrará no aproveitamento de roupas, que saíram de moda, mas cujo tecido, ainda em bom estado, podia ser utilizado:

É comum às senhoras usarem, durante algum tempo, uma certa "toilette", que, com certas audácias, não encontra vulgarização. Essa "toilette”, como é de ver, cai de moda, porque o gosto que a inspirou foi passageiro. Mas o tecido com que ela foi confeccionada, é inteiramente novo e, portanto, aproveitável para outra roupa moderna e de corte diverso. (MARINETTE, n. 54, 1918, s.p.)

Fornecida a lição teórica de economia doméstica, Marinette passa à exposição prática, que consiste em orientar não exatamente as consumidoras de moda, mas as costureiras, pois que serão elas a criar uma roupa moderna a partir de duas outras que ficaram velhas. Para tanto, basta aproveitar, com algumas modificações, o casaco de uma, a saia de outra, e o resultado "[...] fiel reprodução de uma das últimas novidades [...]" (MARINETTE, n. 54, 1918, s.p.) pode ser observado nos desenhos que acompanham a crônica (figura 7). 


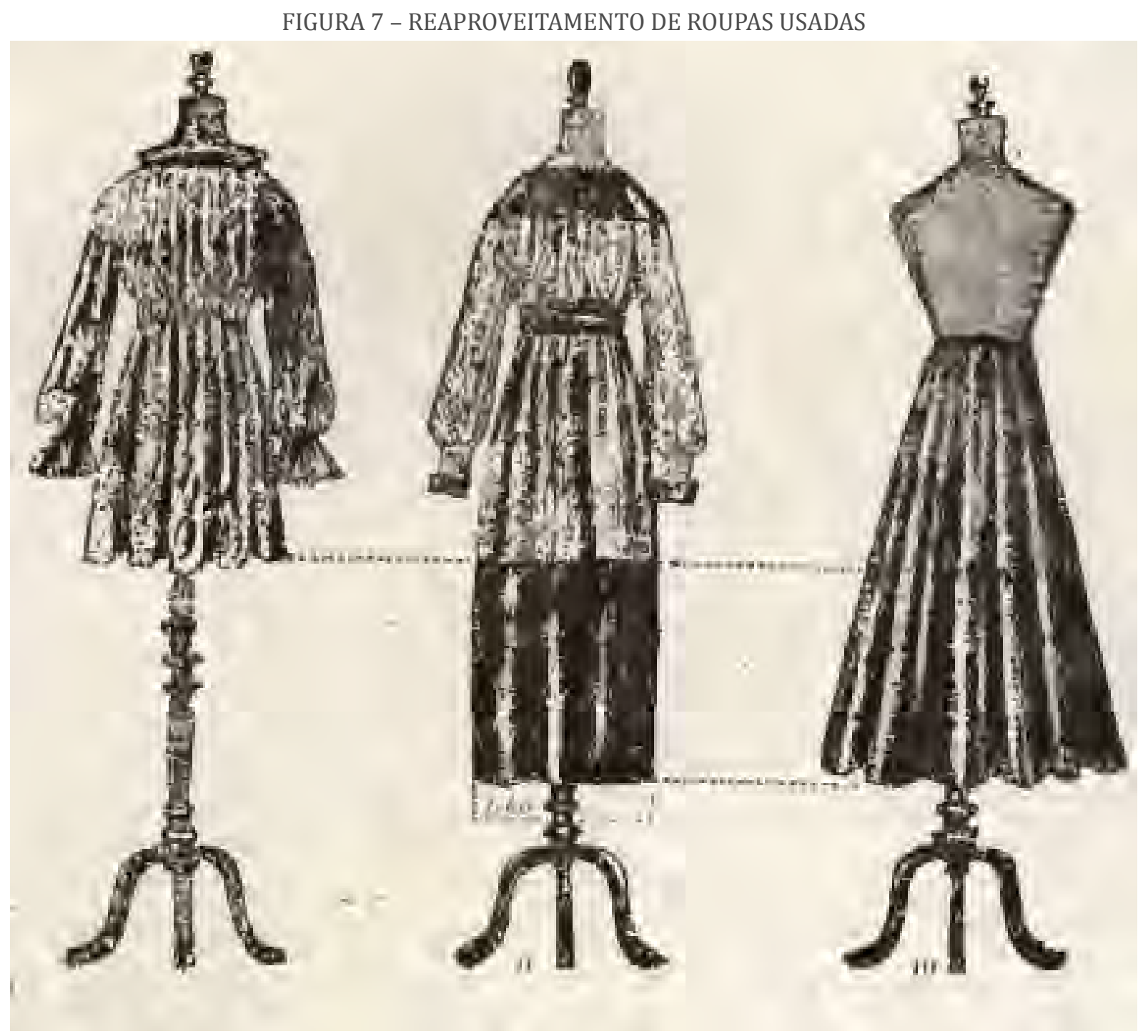

FONTE: Revista Feminina, ano 5, n. 54, novembro de 1918.

A voga da moda econômica, liderada por Marinette, ecoa em algumas ilustrações de artigos sobre moda que saíram na Revista Feminina, como "A moral do vestuário", embora, nesse caso, o desenho de um vestido de passeio, executado com fazendas provenientes do aproveitamento de alguma roupa que saiu de moda (figura 8), não tenha relação com o conteúdo do texto, que discute "[...] pela crescente ousadia com que se tem apresentado a moda das 'toilettes' femininas [...] entremostrando, de uma forma alarmante, encantos que deveriam ficar ocultos" (M.B., n. 45, 1918, s.p.). Sem entrar em detalhes, é possível que a autora esteja se referindo à moda das saias curtas que, proveniente de Paris, as mulheres passaram a usar, mas em nenhum momento o artigo estabelece qualquer vínculo entre $o$ comprimento das saias femininas e a escassez de tecidos durante a guerra. 0 que fica claro, no entanto, no artigo em pauta, é que cabia às brasileiras, acostumadas a imitar indiscriminadamente a moda estrangeira, a responsabilidade pela dissolução moral dos costumes. 


\section{FIGURA 8 - A MODA ECONÔMICA}

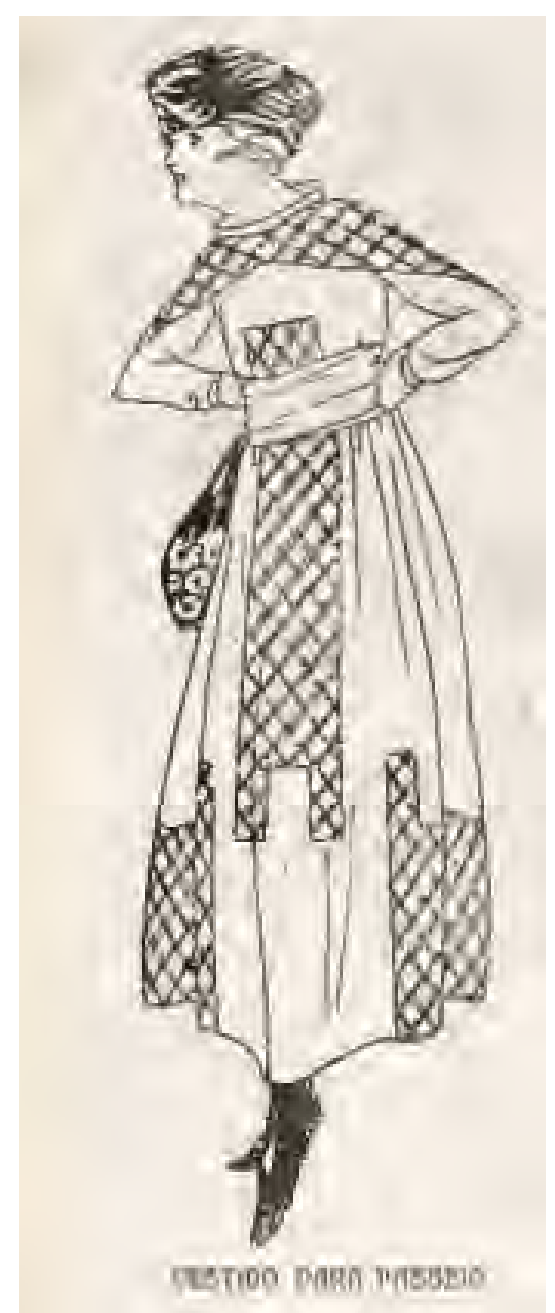

FONTE: Revista Feminina, ano 5, n. 45, fevereiro de 1918.

O repúdio à aceitação incondicional do que vem de fora, sobretudo ao que se refere à moda feminina, reflexo da onda nacionalista que tomou conta do Brasil após a declaração de guerra à Alemanha, é compartilhado por Ana Rita Malheiros, em editorial intitulado "A mulher brasileira após a guerra", ao prescrever às leitoras a missão de recuperar o orgulho e o respeito da pátria nos anos que se seguirem ao conflito europeu:

Sejamos brasileiras, saibamos ser brasileiras, principalmente neste momento agudo e incansável que atravessamos. E para isto a nossa educação tem de despir-se desde logo das robes e manteaux que nos trazem clandestinamente as andorinhas estrangeiras, de todas as roupas usadas, roupas que vêm dos bastidores do mundanismo dissoluto [...] e que nós aceitamos por novas e originais, e que vão custando o preço despropositado da nossa desnacionalização. (MALHEIROS, n. 52,1918 , s.p.) 
Indiferentes aos apelos de Ana Rita Malheiros, e às vésperas do fim da Primeira Guerra Mundial, as crônicas de Marinette e as propagandas de moda continuavam a atrair as leitoras da Revista Feminina para o consumo das novidades provenientes de Paris. A orientação na escolha do tecido adequado para a confecção da indumentária de verão - o crepe da china, o tule, a musselina, o cetim, o organdi, a sarja leve, o fustão - permanecia atrelada à propaganda de lojas, como Mappin Stores e Casa Bonilha, em cujas imagens a escassez de fazendas dá lugar à abundância e à dificuldade de escolha. 0 variado estoque de tecidos oferecido pela Casa Bonilha, de acordo com a propaganda (figura 9), dava mostras de que os navios a serviço do grande magazine não encontravam dificuldades em cruzar o Atlântico para trazer as mais recentes criações da moda parisiense às senhoras brasileiras.

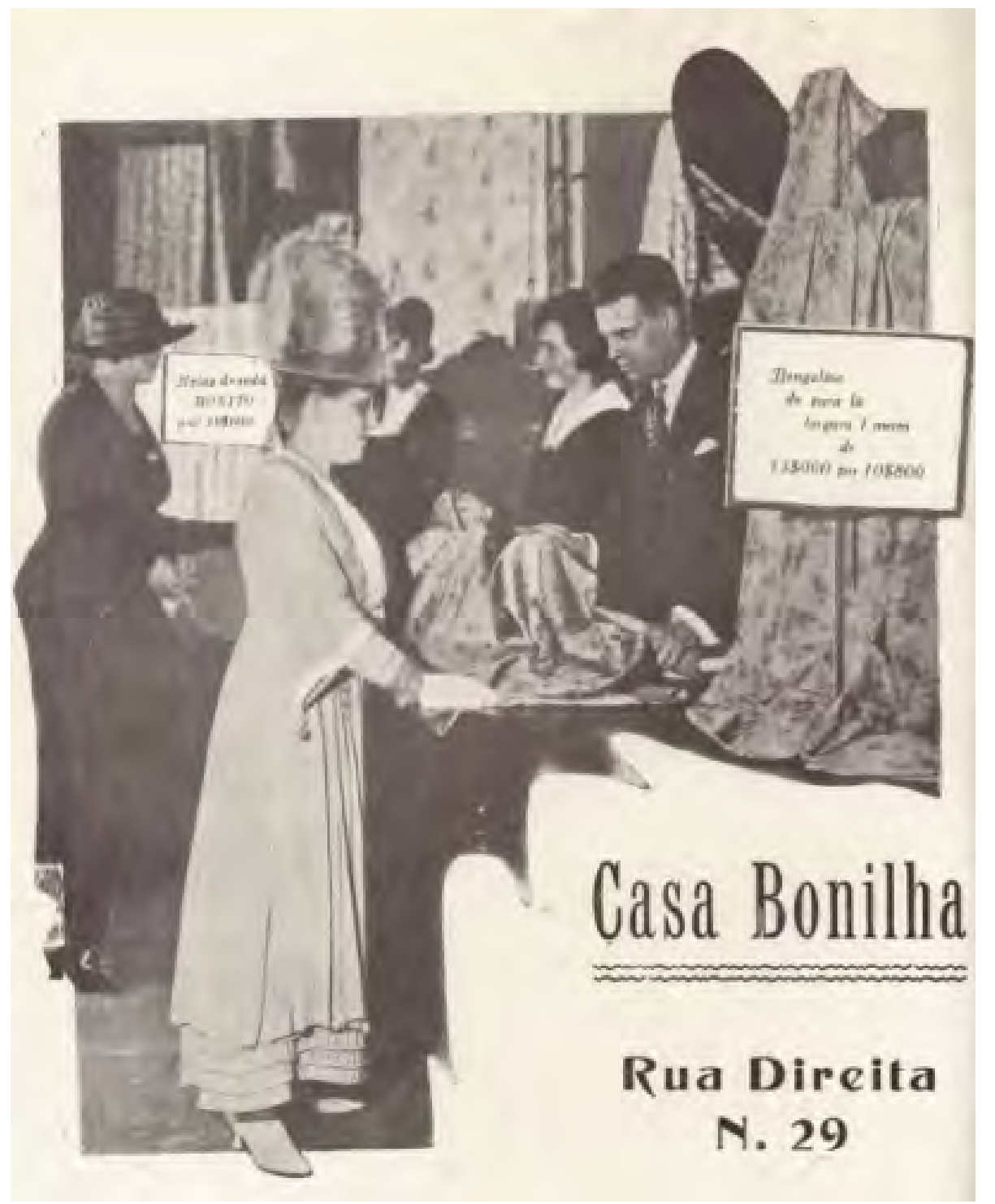

FONTE: Revista Feminina, ano 5, n. 55, dezembro de 1918. 
Os apelos de Marinette a fim de as mulheres fazerem economia nos gastos com a moda podem ser interpretados como uma estratégia política da revista no sentido de se alinhar com o momento de crise econômica nacional e mundial em decorrência da guerra. No entanto, na crônica de setembro de 1918, na qual, em meio às considerações acerca da alta do preço do algodão, "[...] que já se tornou quase inacessível para as bolsas de numerário escasso" (MARINETTE, n. 52, 1918, s.p.), a cronista não deixou de observar que as elegantes da capital paulista continuavam a se dobrar aos ditames da moda:

Entretanto, a despeito dos preços, quase incríveis, das fazendas e dos preços assombrosos que atingiram todos os artigos de comércio, como tecidos, calçados, gêneros alimentícios e outros igualmente indispensáveis, a despeito da crise tremenda que assoberba todas as classes, a população elegante da capital continua a manter, não se sabe por que preço, a mesma atitude, o mesmo luxo e o mesmo gosto de vestir que mantinha na fase, relativamente farta, que antecedeu à atual. (MARINETTE, n. 52, 1918, s.p.)

A autora, porém, não levou avante a reflexão sobre a manutenção dos hábitos de consumo da moda em tempos de guerra, apenas tangenciou o problema e voltou ao posto de "simples cronista da moda":

\footnotetext{
Não curemos de indagar se, para sustentar a elegância a que estavam habituadas, as famílias paulistas têm cortado fundo nos outros orçamentos domésticos, sacrificando os confortos do lar às elegâncias exteriores. Isso são coisas que mais interessam aos srs. psicólogos feministas do que a nós, simples cronista da moda. O que nos preocupa, pelo menos nesse momento, ou melhor, nesta seção, é a moda. Só ela nos enche o espírito e a imaginação. Todos os demais problemas da vida, sem excluir os mais importantes e aqueles que reclamam mais urgente solução, estão relegados para o plano secundário. (MARINETTE, n. 52, 1918, s.p.)
}

Se, por um lado, até o fim do período da guerra, a autora incentivou a contenção de gastos com os luxos do vestuário, por outro lado, tinha consciência de que era essa "população elegante", constituída em grande parte pela mulher citadina moderna, pertencente à classe alta paulistana - ao mesmo tempo alvo e alimento das propagandas da Mappin Stores, da La Saison e da Casa Bonilha que acompanham as crônicas de moda -, a justificar a existência da seção "A Moda", assim como a da Revista Feminina, símbolo do progresso e da modernidade da cidade de São Paulo. Em que pesem os problemas trazidos pelo conflito mundial, no setor de roupas, as leitoras de Marinette viviam "a febre moderna das novidades" (LIPOVETSKY, 2009, p. 11), e, com isso, o assunto guerra acabava sendo sobrepujado pela sedução do fútil, em um momento em que a moda passava a protagonizar valores e significações culturais nas sociedades modernas. 


\section{Referências}

ALVIM, Zuleika; PEIRÃO, Solange. Mappin: 70 anos. São Paulo: Exlibris, 1985.

BONADIO, Maria Claudia. Moda: costurando mulher e espaço público. Estudo sobre a sociabilidade feminina na cidade de São Paulo. 1913-1929. 2000. 184 f. Dissertação (Mestrado em História) - Departamento de História, Faculdade de Filosofia, Letras e Ciências Humanas, Unicamp, Campinas. Disponível em: http://repositorio.unicamp.br/ jspui/handle/REPOSIP/279499. Acesso em: 15 jul. 2019.

BUITONI, Dulcília. Mulher de papel. São Paulo: Loyola, 1981.

CAVALCANTI, Pedro; DELION, Luciano. São Paulo a juventude do centro. São Paulo: Grifo, 2004.

LIMA, Paula Coelho Magalhães de. A exposição de 1917 no Palácio das Indústrias de São Paulo: representações do industrialismo na metrópole nascente. In: VI Colóquio LatinoAmericano sobre Representação e Preservação do Patrimônio Industrial, 2012, São Paulo. Anais... p. 1-23. Disponível em: http://portal.iphan.gov.br/uploads/ckfinder/arquivos/VI_ coloquio_t3_exposicao_1917.pdf. Acesso em: 10 jul. 2018.

LIPOVETSKY, Gilles. 0 império do efêmero: a moda e seu destino nas sociedades modernas. Trad. Maria Lúcia Machado. São Paulo: Companhia das Letras, 2009.

LOPES, Sandra Lúcia. Espelho da mulher: Revista Feminina (1916-1925). 1991. 234 f. Tese (Doutorado em História Social) - Faculdade de Filosofia, Letras e Ciências Humanas, USP, São Paulo.

M. B. A moral do vestuário. Revista Feminina, São Paulo, ano 5, n. 45, fev. 1918, p. 46.

MALHEIROS, Ana Rita. A mulher brasileira após a guerra. Revista Feminina, São Paulo, ano 5, n. 52, set. 1918, s.p.

MALHEIROS, Ana Rita. A mulher brasileira na guerra. Revista Feminina, São Paulo, ano 5, n. 45, fev. 1918, s.p.

MALHEIROS, Ana Rita. A mulher brasileira na guerra. Revista Feminina, São Paulo, ano 4, n. 43, dez. 1917, s.p.

MALHEIROS, Ana Rita. Editorial. Revista Feminina, São Paulo, ano 4, n. 42, nov. 1917, s.p.

MARINETTE. A Moda. Revista Feminina, São Paulo, ano 5, n. 52, set. 1918, s.p.

MARINETTE. A moda e a guerra. Revista Feminina, São Paulo, ano 5, n. 51, ago. 1918, s.p.

MARINETTE. A Moda. Revista Feminina, São Paulo, ano 2, n. 13, jun. 1915, p. 7. 
MARINETTE. A Moda. Revista Feminina, São Paulo, ano 2, n. 14, jul. 1915, p. 18.

MARINETTE. A Moda. Revista Feminina, São Paulo, ano 2, n. 15, ago. de 1915, p. 18.

MARINETTE. A Moda. Revista Feminina, São Paulo, ano 2, n. 16, set. 1915, p. 17.

MARINETTE. A Moda. Revista Feminina, São Paulo, ano 3, n. 22, mar. 1916, p. 25.

MARINETTE. A Moda. Revista Feminina, São Paulo, ano 3, n. 26, jul. 1916, p. 22.

MARINETTE. A Moda. Revista Feminina, São Paulo, ano 3, n. 29, out. 1916, p. 20.

MARINETTE. A Moda. Revista Feminina, São Paulo, ano 4, n. 34, mar. 1917, s.p.

MARINETTE. A Moda. Revista Feminina, São Paulo, ano 4, n. 37, jun. 1917, s.p.

MARINETTE. A Moda. Revista Feminina, São Paulo, ano 4, n. 39, ago. 1917, s.p.

MARINETTE. A Moda. Revista Feminina, São Paulo, ano 4, n. 40, set. 1917, s.p.

MARINETTE. Elegâncias com roupas usadas. Revista Feminina, São Paulo, ano 5, n. 54, nov. 1918 , s.p.

MARINETTE. Feminismo e guerra. Revista Feminina, São Paulo, ano 5, n. 54, nov. 1918, s.p.

MARINETTE. Feminismo e guerra. Revista Feminina, São Paulo, ano 5, n. 54, nov. 1918, s.p.

MONTEIRO, Marcelo. U-93: a entrada no Brasil na Primeira Guerra Mundial. Porto Alegre: BesouroBox, 2014.

O TRAJE masculino e as mulheres. Revista Feminina, São Paulo, ano 5, n. 53, out. 1918, s.p.

REG0, Ana Regina; LEAL, Ranielle. Imprensa brasileira na Primeira Grande Guerra: intelectuais em ação. ALCAR, 2015. 10º Encontro Nacional de História da Mídia, UFRGS/ Porto Alegre/Rio Grande do Sul, 3 a 5 de junho de 2015, p. 1-18. Disponível em: http:// www.ufrgs.br/alcar/encontros-nacionais-1/encontros-nacionais/10o-encontro-2015/gthistoria-da-midia-impressa/imprensa-brasileira-na-primeira-guerra-mundial-intelectuaisem-acao/at_download/file. Acesso em: 11 jul. 2018.

VENCEM as mulheres na Inglaterra e nos Estados Unidos! Direito ao voto feminino. Revista Feminina, São Paulo, ano 5, n. 45, fev. 1918, s.p.

VINHOSA, Francisco Luiz Teixeira. O Brasil e a Primeira Guerra Mundial: a diplomacia brasileira e as grandes potências. Rio de Janeiro: Instituto Histórico e Geográfico Brasileiro, 1990. 